\title{
Short Communication: Population and stand structure of Cinnamomum sintoc in the Low Land Forest of Mount Ciremai National Park, West Java, Indonesia
}

\author{
AGUS YADI ISMAIL ${ }^{12, \bullet}$, CECEP KUSMANA ${ }^{3, \bullet \bullet}$, EMING SUDIANA ${ }^{4}$, PUDJI WIDODO ${ }^{4,}$ \\ ${ }^{1}$ Doctoral Program of Biology, University of Jenderal Soedirman (UNSOED), Jl. Dr. Soeparno 63, Purwokerto, Banyumas 53122, Central Java, \\ Indonesia. Tel.: +62-81222177363. `email: agus.yadi@uniku.ac.id. \\ ${ }^{2}$ Faculty of Forestry, Kuningan University Jalan Tjut Nyak Dhien Cijoho Kuningan, Central Java, Indonesia. \\ ${ }^{3}$ Department of Silviculture, Faculty of Forestry, Bogor Agricultural University (IPB), IPB Dramaga Campus, Dramaga, PO Box 168, Bogor 16680, \\ West Java, Indonesia. Tel.: +62-251-8626806, Fax.: +62-251-8626886, ^^email: ckmangrove@ gmail.com. \\ ${ }^{4}$ Faculty of Biology, University of Jenderal Soedirman (UNSOED), J1. Dr. Soeparno 63, Purwokerto, Banyumas 53122, Central Java, Indonesia
}

Manuscript received: 21 January 2019. Revision accepted: 19 March 2019.

\begin{abstract}
Ismail AY, Kusmana C, Sudiana E, Widodo P. 2019. Short Communication: Population and stand structure of Cinnamomum sintoc in the Low Land Forest of Mount Ciremai National Park, West Java, Indonesia. Biodiversitas 20: 1042-1047. Cinnamomum $\operatorname{sintoc}(C$. sintoc) is one of the anthelmintic and anti-inflammatory medicinal plants which produces essential oils from its roots, skin, and leaves. This study aimed to analyze the population and stand structure of $C$. sintoc in Mount Ciremai National Park, West Java, Indonesia. Data collection was carried out using plots/ strips method. The plots were purposively placed and made at each altitude and direction of the slope. The research recorded 804 individual trees from each growth edge. Individual density between slope directions and altitudes was not significantly different for all diameter classes, but was significantly different between slope directions of stratum B $(\mathrm{P}=0.001)$ and $\mathrm{E}(\mathrm{P}=0.012)$. These results indicate that sintoc population is spread evenly and can be cultivated at various slope and altitude directions and has no preference for the two topographic variables.
\end{abstract}

Keywords: Cinnamomum sintoc, Mount Ciremai National Park, population, stand structure

\section{INTRODUCTION}

Mount Ciremai National Park (MCNP) with an area of 15,500 ha is a natural conservation area functions as a protection area for plants and animals. Several types of local plants in MCNP are saninten (Castanopsis argentea), rasamala (Altingia excelsa), pasang (Quercus sundaica), puspa (Schima wallichii), teureup/tekalong/benda (Artocarpus elasticus), jamuju (Podocarpus imbricatus) and huru sintok (Cinnamomum sintoc). C. sintoc is one of the rare and endangered plant herbs (Kastolini 2018; Hidayat and Risna 2007). Sintoc can produces essential oils - as many as 30 components - out of roots, stem bark, and leaves. Bark extract from $C$. sintoc is source for anti-biofilm agents for treatment of infections caused by Pseudomonas aeruginosa and Staphylococcus aereus biofilm (Pratiwi et al. 2014). Wiart (2013) stated that sintoc was used by native of the Malay coast of New Guinea as a medicinal plant for chronic diarrhea and as an antipasmodic. Besides, C. sintoc is also used by local community in Poncokusumo Subdistrict, Malang District, East Jawa Province, Indonesia for treating tuberculosis and vitality (Batoro dan Siswanto 2017).

Sintok can be found in Java, Sumatra and Kalimantan Islands (Lemmens and Soerianegara 1995). This plant tends to grow solitary and is rarely found in a cluster. There is a gap in number of populations between tree and seedling stage, so that $C$. sintoc has difficulty regenerating in its natural habitat (Hidayat 2006).
The population of $C$. sintoc in Java tends to decrease (Rifai et al. 1992). Although being classified as a rare plant, sintoc can still be found in MCNP forest ecosystems, but the population conditions are not yet widely known. Conservation of $C$. sintoc population in MCNP area requires studies on the abundance and distribution of $C$. sintoc population in MCNP. Based on that the above description, this study aimed to analyze the population and stand structure of $C$. sintoc. The results are expected to provide information about the population and become a reference for the use of species to prevent it from extinction and to further develop its cultivation

\section{MATERIALS AND METHODS}

\section{Study site}

This research was carried out during June to August 2017 in Mount Ciremai National Park (MCNP). The reserach sites covered two districts of Kuningan and Majalengka, West Jawa Province of Indonesia (Figure 1). Geographically, MCNP is located at $108^{\circ} 28^{\prime} 0^{\prime \prime}$ E$108^{0} 21$ '35" East longitude, and 6050'25" S - 6058'26" South latitude. Ciremai Mountain is the highest mountain in West Java with the highest peak of of $3078 \mathrm{~m}$ asl and forms a cone on the north side as the remains of Geger Halang caldera of $4.5 \times 5 \mathrm{~km}^{2}$ area size. Based on Schmidt \& Fergusson classification (1951), MCNP has a B and C 
climate types with an average rainfall of 2,000-4,000 mm year $^{-1}$. The monthly temperatures of the research site ranged from $18^{\circ} \mathrm{C}$ to $22^{\circ} \mathrm{C}$. The topography of MCNP was varied, ranging from ramps to steep slopes. The ramp slopes of MCNP area (0-8\%) was about $26.52 \%$, and the slopes above $8 \%$ was $73.48 \%$ of the total area.

\section{Vegetation analysis}

Data collection was permormed using plots/strips method. The plots/strips were placed at each direction of slopes and altitude interval above sea level. The starting point to place the sample of strips/plots in each slope direction and altitude was the point where $C$. sintoc was first encountered. The sample plots were made in a nested design, i.e., sample plots measuring $20 \mathrm{~m}$ x $20 \mathrm{~m}$ for tree inventory (woody plants with diameter at breast high of > $20 \mathrm{~cm}$ ), $10 \mathrm{~m} \times 10 \mathrm{~m}$ subplots for pole inventory (woody plants with diameter at breast high of $10-20 \mathrm{~cm}), 5 \mathrm{~m} \times 5 \mathrm{~m}$ subplots for sapling inventory (wood plants with diameter at breast high $<10 \mathrm{~cm}$ and height $>1.5 \mathrm{~m}$ ), and $2 \mathrm{~m} \mathrm{x} 2 \mathrm{~m}$ subplots for seedling inventory (woody plants with height $\leq 1.5 \mathrm{~m}$ ) (Kusmana and Istomo, 1995). For vertical and horizontal structures, data were divided into stem diameter classes and tree height classes (Table 1).

Table 1. Classification of stem diameter and tree height

\begin{tabular}{cccc}
\hline \multicolumn{2}{c}{ Vertical structure } & \multicolumn{2}{c}{ Horizontal structure } \\
\hline $\begin{array}{c}\text { Tree height } \\
\text { classes }(\mathbf{m})\end{array}$ & Stratum & $\begin{array}{c}\text { Stem diameter } \\
\text { stage }(\mathbf{c m})\end{array}$ & $\begin{array}{c}\text { Diameter } \\
\text { class codes }\end{array}$ \\
\hline$>30$ & $\mathrm{~A}$ & $10-20$ & $\mathrm{~A}$ \\
$20-30$ & $\mathrm{~B}$ & $21-30$ & $\mathrm{~B}$ \\
$4-20$ & $\mathrm{C}$ & $30-40$ & $\mathrm{C}$ \\
$1-4$ & $\mathrm{D}$ & $41-50$ & $\mathrm{D}$ \\
$<1$ & $\mathrm{E}$ & $>50$ & $\mathrm{E}$ \\
\hline
\end{tabular}

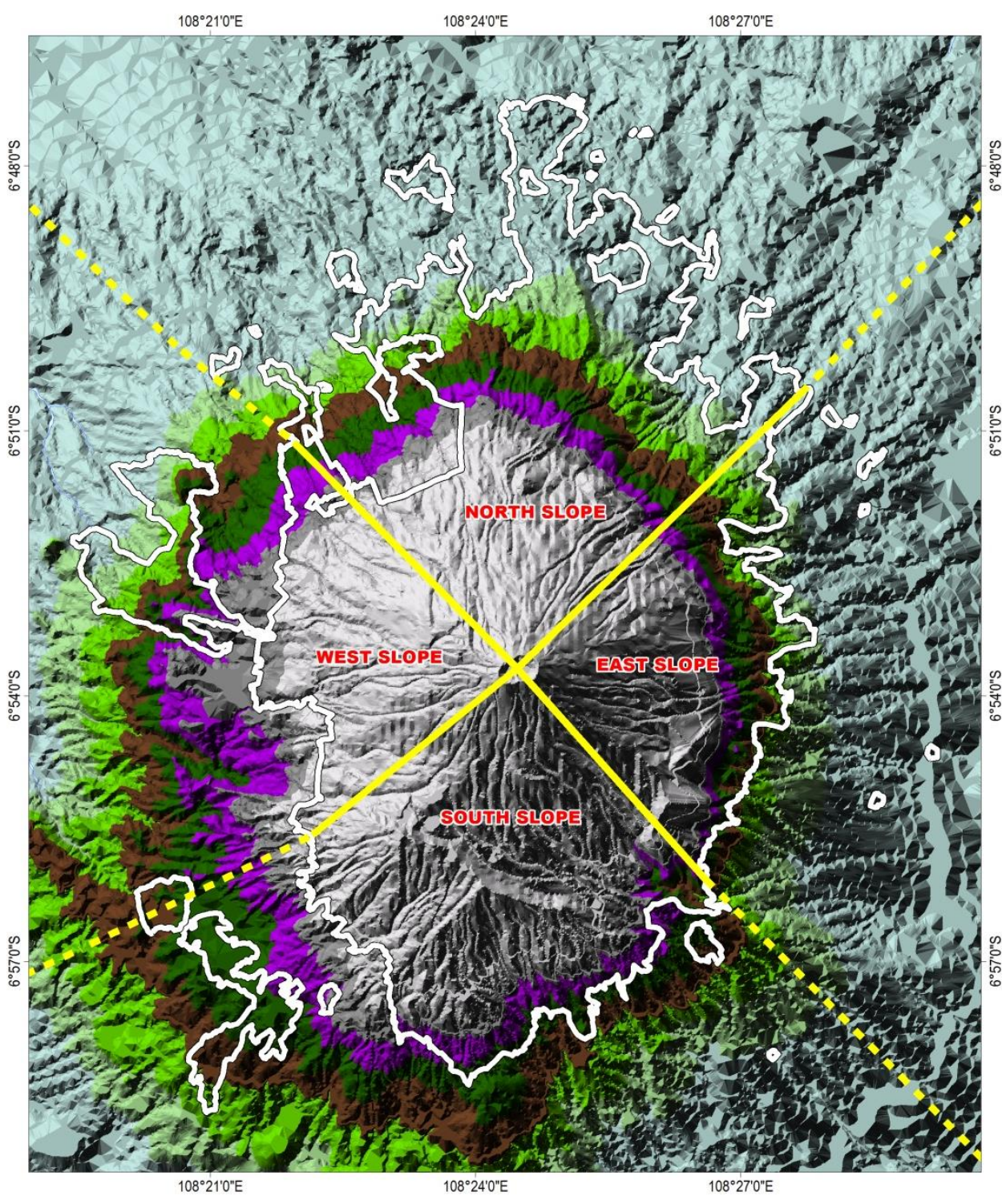

Figure 1. The research location in Mout Ciremai, West Java Province of Indonesia
MAP OF RESEARCH LOCATION

IN CIREMAI MOUNTAIN NATIONAL PARK KUNINGAN AND MAJALENGKA DISTRICTS PROVINCE OF WEST JAVA SCALE $1: 105.000$

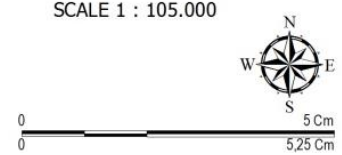

\section{Elevation}

In Meters Above

Sea Level (MASL)

$\square>1.300$

$1.200-1.300$

$1.100-1.200$

$1.100-1.200$
$1.000-1.100$

$900-1.000$

$800-900$

$700-800$

$<700$

$\square$ Ciremai Mountain

- Road

— River

Four Slope Directions
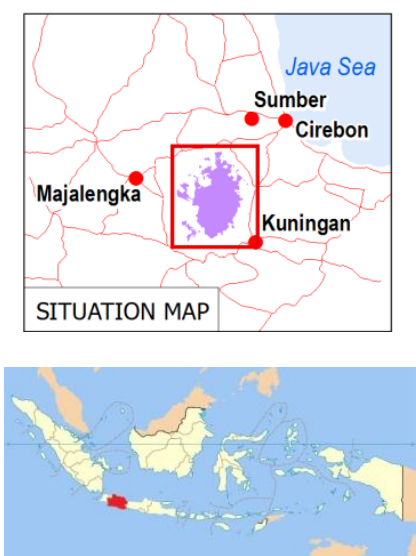


\section{Data analysis}

Descriptive method was used in data analysis to determine the population condition, while the difference of means test was applied to find out the difference of tree density in some plant characteristics. First thing to do in before testing the difference of means was to perform data homogeneity test to determine data distribution and decide which test to be taken: parametric or non-parametric. ttudent test was applied for homogeneous distribution data, while Mann-Whitney test was for heterogeneous distribution data. Both analysis approaches were performed by using SPSS 25 software assistance. The variables used were stem diameter class $(\mathrm{cm})$ and tree height class $(\mathrm{m})$ for dependent variables, and the place altitude ( $\mathrm{m}$ asl) and slope direction for independent variables. Whereas, the density of trees and Import Value Index (IVI) of species were calculated using the formulas of Odum (1996).

\section{RESULTS AND DISCUSSION}

\section{Dominant tree species}

A total of 631 sample plots were observed in the present study. The sample pots spread across seven altitude classes from each of the four slope directions. The results of the study revealed that the tree species which dominated the habitat of $C$. sintoc were pine (Pinus merkusii), african wood (Maesopsis eminii), weeping fig/ficus (Ficus benjamina), bishop wood (Bischofia javanica), and gnemon tree/melinjo (Gnetum gnemon) (Table 2).

\section{Population density and distribution of Cinnamomum sintoc}

C. sintoc was found in four slope classes, ranging in from the altitudes of 500 to $1200 \mathrm{~m}$ asl. Sintoc density of all slope and altitude classes was 163 ind $\mathrm{ha}^{-1}$ for tree growth stage and 306 ind ha-1 for pole growth stage (Table 3 ). The spatial distribution of $C$. sintoc in MCNP can be seen on Figure 2.

\section{Horizontal structure of Cinnamomum sintoc}

Diameter of $C$. sintoc species on the of tree growth stage, in general, ranged from $10-60 \mathrm{~cm}$ (Figure 3). The largest stem diameter class distribution of trees in all slope classes was in the $10-20 \mathrm{~cm}$ diameter class. Tree density decreased with the increase of diameter class.

The mean difference test was done to determine the level of density difference in each diameter class between altitudes and between slope directions. The result showed that there was no difference in density of $C$. sintoc at each stem diameter class (Table 4).

\section{Vertical structure of Cinnamomum sintoc}

$C$. sintoc was found on four slope directions, starting from stratum $\mathrm{C}, \mathrm{D}$, to $\mathrm{E}$. No individual tree was found in strata A and B (Figure 4).

The mean difference test revealed that the tree density in each stratum was not significantly different of between altitudes, except for stratum B and E of between slope directions (Table 5).
Table 2. Dominant tree species at four slope directions of the study site

\begin{tabular}{lc}
\hline Name of species & IVI (\%) \\
\hline West slope direction & \\
Maesopsis eminii & 29.21 \\
Ficus benjamina & 28.83 \\
Cinnamomum sintoc & 28.27 \\
Swietenia mahagoni & 27.12 \\
Hibiscus macrophyllus & 20.40 \\
Sterculia oblongata. & 15.68 \\
Murraya paniculata & 13.62 \\
Artocarpus heterophyllus & 12.43 \\
& \\
East slope direction & \\
Pinus merkusii. & 76.29 \\
Swietenia mahagoni & 19.05 \\
Bischofia javanica & 17.18 \\
Alstonia scholaris & 15.16 \\
Zyzygium polyanthum & 14.50 \\
Cinnamomum sintoc & 14.39 \\
Hibiscus macrophyllus & 14.38 \\
Castanopsis argentea & 12.82 \\
South slope direction & \\
Pinus merkusii & \\
Maesopsis eminii & 44.88 \\
Hibiscus macrophyllus & 30.66 \\
Persea Americana & 26.39 \\
Cinnamomum sintoc & 18.97 \\
Dysoxylum ramiflorum & 16.28 \\
Artocarpus heterophyllus & 12.47 \\
Ficus indica & 11.70 \\
North slope direction & 10.21 \\
Pinus merkusii & \\
Cinnamomum sintoc & \\
Gnetum gnemon & \\
Schima wallichii & \\
Sterculia oblongata & 16.89 \\
Artocarpus sp. & 13.10 \\
Dillenia excelsa & 9.38 \\
Zyzygium polyanthum & 8.14 \\
& 7.11 \\
& 6.76 \\
& \\
& \\
& \\
&
\end{tabular}

\section{Discussion}

Data collection was conducted on 672 sample plots which recorded 7452 individual trees, 142 tree species, and habitat was dominated by cultivated trees such as Pinus merkusii, Maesopsis eminii and Gnetum gnemon. The results showed that $C$. sintoc was able to grow in secondary forest and disturbed habitat modification. This study also indicates that $C$. sintoc is a species able to adapt to the changing environment. Wuu Kuang (2006) stated that Cinnamomum species can live in primary or secondary forests. Our results are in line with Pesiu et al. (2016), who found $C$. sintoc in secondary forest in Pulau Bidong (Trengganu Island). Wuu-Kuang (2006) and Sujarwo and Arinasa (2014) reported that sintoc can live in an open area with adequate amount of sunlight. In addition, Putri et al. (2017) showed that $C$. sintoc was found in the karst ecosystem at Mt. Nyungcung, Bogor Regency at 193-218 $\mathrm{m}$ above sea level (asl). 
In the presnt study, C.sintoc was found in altitude range of 500 to $1200 \mathrm{~m}$ asl, indicating that $C$. sintoc can grow in the lowland (0-1000 $\mathrm{m}$ asl) forest and sub-montana (1000$3300 \mathrm{~m}$ asl) forest. These results are in line with that of Susiarti et al. (2018), who found $C$. sintoc in the lowland forest at Bodogol, Mount Gede Pangrango National Park, West Java. Hidayat and Risna (2007) and Lemmens and Soerianegera (1995) found C. sintoc in altitude of 1036$2330 \mathrm{~m}$ asl and is commonly grown in hills and mountain forests up to an altitude of $2400 \mathrm{~m}$. In Biodiversity Park in Sumedang Regency, $C$. sintoc was also found in hilly and mountainous area in altitude range 25 to $1667 \mathrm{~m}$ asl (Kastolini 2018).

Cinnamomum sintoc population can spread in the lowland forest $(2-1000 \mathrm{~m}$ asl) and sub-mountain (1000$3000 \mathrm{~m}$ asl) ecosystems due to several factors. The pattern of plant distribution in a plant community can be caused by wind, water availability, light intensity, reproductive ability of organisms, social aspects involving plant phenology, coactive as effects of intraspecific interactions (Ludwig and Reynolds 1988), nutrient content, soil acidity, host rock, topography (Ewusie 1990; Kurniawan and Parekesit 2008; Yuanjie et al. 2010), moisture gradient (Zelnik and Carni 2008), slope gradient, slope aspect, and elevation (Yuanjie et al. 2010).

The results showed that $C$. sintoc was found mostly in the southwestern and eastern parts of the study site. Tree density of $C$. sintoc in the lowland forest of Ciremai is lower (1-17 ha $\mathrm{ha}^{-1}$ ) than that in Ranu Pani, Senduro dan Pronojiwo Resort in Bromo-Tengger Semeru Taman Nasional (22 ind $\mathrm{ha}^{-1}$ ) (Hidayat and Risna 2017). However, the density of sintoc for each diameter class between the altitudes and between the slope directions was not significantly different. This indicates that sintoc species is able to grow at various altitudes and is quite tolerant to the environments with different duration of direct sunlight exposure. Our results revealed that $C$. sintoc has any habitat preference to particular topographic variables, thus it can be classified as a generalist species.

Table 3. Density of tree pole boles and trees at each altitude class and slope direction

\begin{tabular}{|c|c|c|c|}
\hline \multirow{2}{*}{ Slope direction } & \multirow{2}{*}{$\begin{array}{l}\text { The altitude } \\
\text { (m asl) }\end{array}$} & \multicolumn{2}{|c|}{ Density (ind ha' ${ }^{-1}$ ) } \\
\hline & & Pole & Tree \\
\hline \multirow[t]{6}{*}{ West } & 600 & 13 & 8 \\
\hline & 700 & 8 & 12 \\
\hline & 800 & 4 & 8 \\
\hline & 900 & 8 & 10 \\
\hline & 1000 & 19 & 2 \\
\hline & Total & 52 & 40 \\
\hline \multirow[t]{6}{*}{ South } & 500 & 20 & 15 \\
\hline & 800 & 16 & 5 \\
\hline & 900 & 7 & 7 \\
\hline & 1000 & 0 & 3 \\
\hline & 1200 & 13 & 3 \\
\hline & Total & 56 & 33 \\
\hline \multirow[t]{8}{*}{ East } & 500 & 5 & 6 \\
\hline & 600 & 13 & 6 \\
\hline & 700 & 21 & 2 \\
\hline & 800 & 19 & 5 \\
\hline & 900 & 0 & 9 \\
\hline & 1000 & 13 & 9 \\
\hline & 1100 & 33 & 17 \\
\hline & Total & 104 & 54 \\
\hline \multirow[t]{8}{*}{ North } & 500 & 7 & 7 \\
\hline & 600 & 27 & 8 \\
\hline & 700 & 48 & 7 \\
\hline & 800 & 6 & 6 \\
\hline & 900 & 2 & 4 \\
\hline & 1000 & 4 & 4 \\
\hline & Total & 94 & 36 \\
\hline & Grand Total & 306 & 163 \\
\hline
\end{tabular}

Table 4. Mean sepatarions of Cinnamomum sintoc tree density in each diameter class between altitudes and between slope directions

\begin{tabular}{ccccccc}
\hline Tree size & \multicolumn{3}{c}{ Between altitude } & \multicolumn{3}{c}{ Between slope direction } \\
\cline { 2 - 7 } stratification & Name of test & $\mathbf{P}$ & & Name of test & P \\
\hline A & t-student & 0.251 & $(\mathrm{~ns})$ & t-student & 0.142 & $(\mathrm{~ns})$ \\
B & Mann-Whitney & 0.367 & $(\mathrm{~ns})$ & t-student & 0.072 & $(\mathrm{~ns})$ \\
C & t-student & 0.492 & $(\mathrm{~ns})$ & t-student & 0.441 & $(\mathrm{~ns})$ \\
D & Mann-Whitney & 0.069 & $(\mathrm{~ns})$ & t-student & 0.307 & $(\mathrm{~ns})$ \\
E & Mann-Whitney & 0.949 & (ns) & t-student & 0.069 & $(\mathrm{~ns})$ \\
\hline
\end{tabular}

Note: $\mathrm{ns}=$ non-significant; $\mathrm{s}=$ significant (at $\alpha: 5 \%)$

Table 5. Mean sepatarions of tree density at each stratum of between altitudes and between slope directions

\begin{tabular}{ccccccc}
\hline Tree size & \multicolumn{2}{c}{ Between altitude } & \multicolumn{3}{c}{ Between slope direction } \\
\cline { 2 - 7 } stratification & Name of test & $\mathbf{P}$ & & \multicolumn{2}{c}{ Name of test } & P \\
\hline A & Mann-Whitney & 0,695 & (ns) & Mann-Whitney & 0,058 & $(\mathrm{~ns})$ \\
B & Mann-Whitney & 0,921 & (ns) & Mann-Whitney & 0,001 & $(\mathrm{~s})$ \\
C & t-student & 0,069 & (ns) & t-student & 0,258 & $(\mathrm{~ns})$ \\
D & Mann-Whitney & 0,880 & (ns) & t-student & 0,685 & $(\mathrm{~ns})$ \\
E & Mann-Whitney & 0,754 & (ns) & Mann-Whitney & 0,012 & (s) \\
\hline
\end{tabular}

Description: $\mathrm{ns}=$ non-significant; $\mathrm{s}=$ significant $($ at $\alpha: 5 \%)$ 


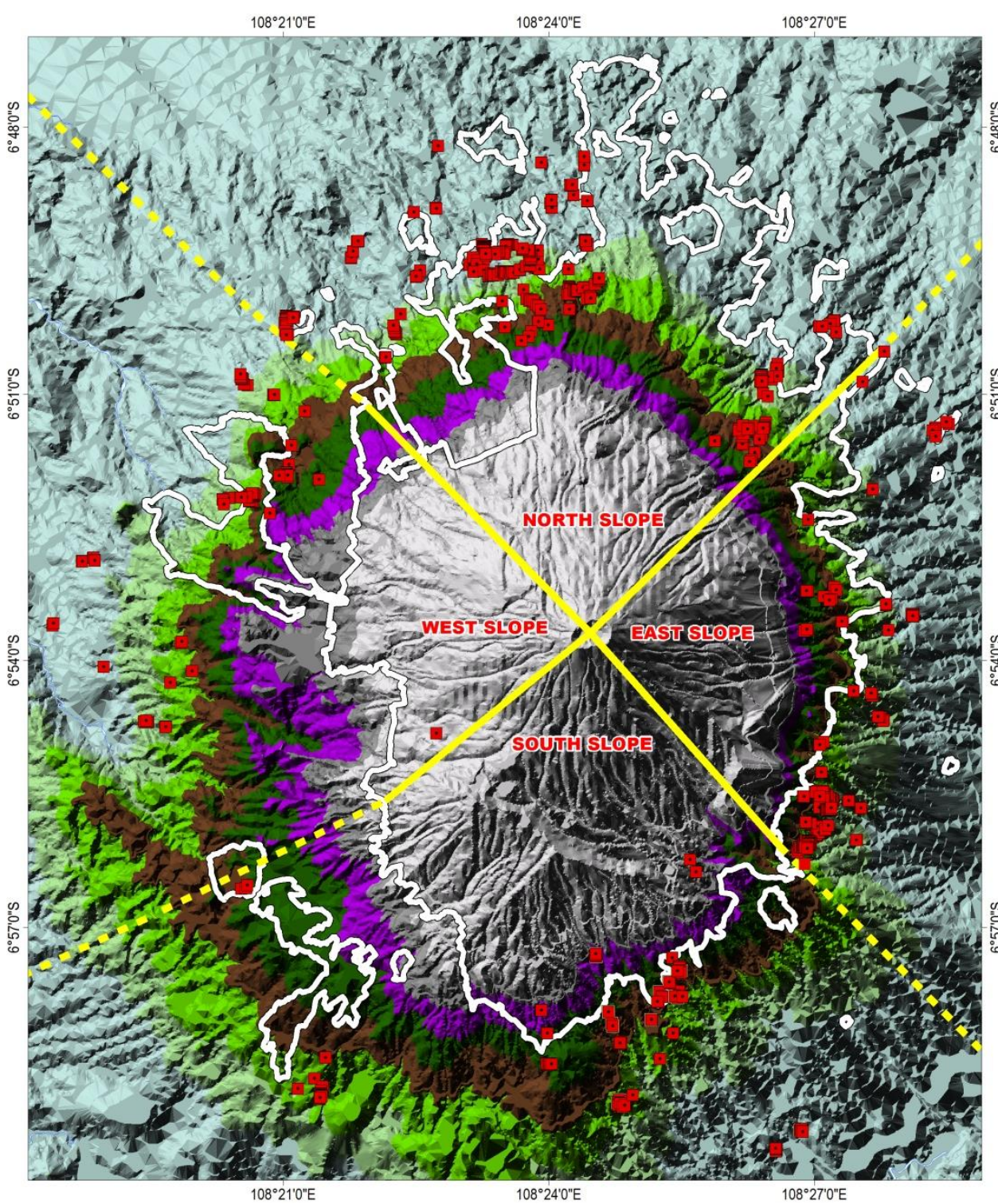

MAP OF DISTRIBUTION

CINNAMOMUM SINTOC

IN CIREMAI MOUNTAIN NATIONAL PARK KUNINGAN AND MAJALENGKA DISTRICTS PROVINCE OF WEST JAVA

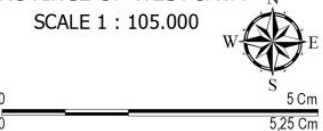

Elevation

In Meters Above

Sea Level (MASL)

$\square>1.300$

$1.200-1.300$
$1.100-1.200$

$1.000-1.100$

$900-1.000$

$800-900$

$700-800$
$<700$

$\square$ Ciremai Mountain

Road

River

Four Slope
Directions

- Cinnamomum

Sintoc
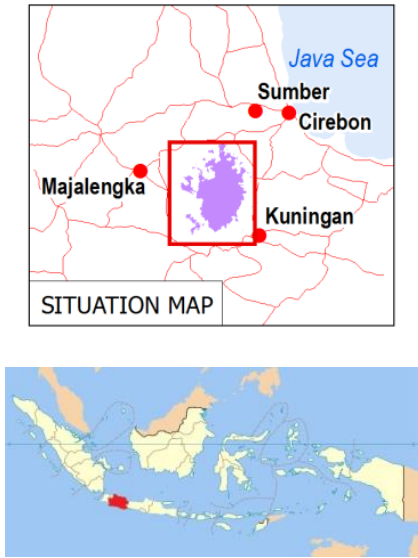

Figure 2. Cinnamomum sintoc spatial distribution at Mount Ciremai National Park, West Java Province of Indonesia

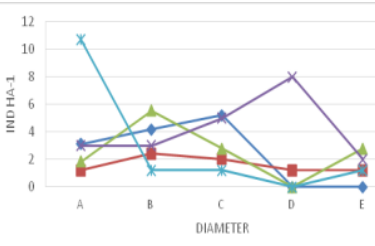

A

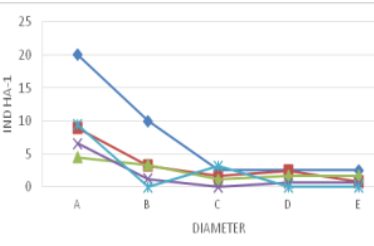

B

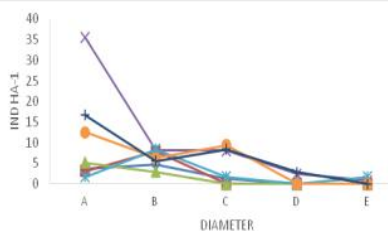

C

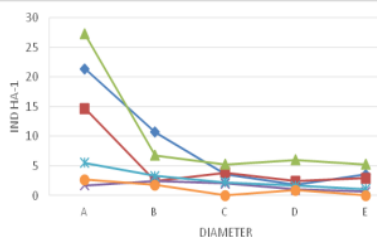

D

Figure 3. Stem diameter class distribution of Cinnamomum sintoc tree stand $(\mathrm{cm})$. A. West, B. South, C. East, D. North. Diameter Class: $\mathrm{A}=10-20 \mathrm{~cm}, \mathrm{~B}=21-30 \mathrm{~cm}, \mathrm{C}=31-40 \mathrm{~cm}, \mathrm{D}=41-50 \mathrm{~cm}, \mathrm{E}=>50 \mathrm{~cm}$

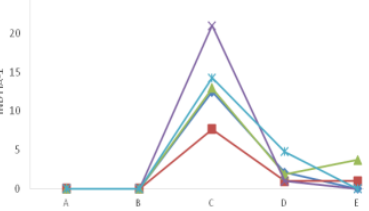

A

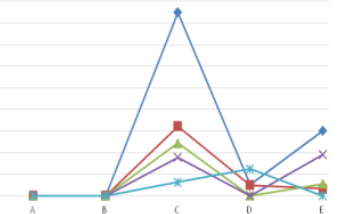

B

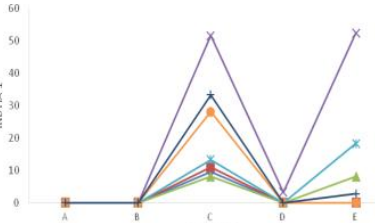

C

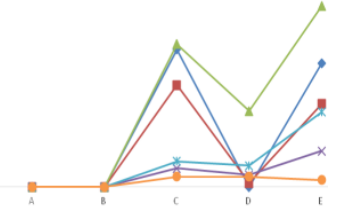

sтratum

D

Figure 4. Crown height class of Cinnamomum sintoc tree stand (m). A. West, B. South, C. East, D. North 
Stratification of vegetation is also known as stratum or strata. Strata is a grouping of plants based on height for vertical space and tree diameter for horizontal space. Stratification is determined based on crown height because each species has a different maximum height, in which crown of the same species lies in different strata (Baker and Wilson 2000). Vertical structure or stratification of a stand is seen from the stand height distribution. Based on vertical structure, $C$. sintoc stand was dominated by $\mathrm{C}$ stratum (420 ), suggesting that $C$. sintoc stand in the lowland forest of Mount Ciremai National Park was still in the growth phase.

In the horizontal structure, sintoc was found in the stem diameter class of $10-20 \mathrm{~cm}, 20-30 \mathrm{~cm}$, and $30-40 \mathrm{~cm}$. This phenomenon shows that $C$. sintoc is still able to regenerate even in a disturbed ecosystem that has undergone modification. In this study, sintoc density in $10-20 \mathrm{~cm}$ stem diameter class was higher than that of the individual density in the above stem diameter classes. This result is in line with that of Oladoye et al. (2014), who found that the number of individual trees decreased along with the increase of stem diameter of the trees. The result also indicates that the lowland forest of Mount Ciremai National Park was in the mid-level succession. This data also provides supporting information that $C$. sintoc has the capability to regenerate and its sustainability can be guaranteed as long as there is no logging activity on the species.

As a species with a high economic value since it is a medicinal plant, the presence of $C$. sintoc needs to be maintained and multiplied in population. The results of this study have provided information that $C$. sintoc can be developed or cultivated in diverse environments including cultivated lands ranging from lowlands to highlands.

In conclusion, the tree population of $C$. sintoc was found ain Mount Ciremai National Park at an altitude of 500-1200 $\mathrm{m}$ asl with the density ranged from 2 ind $^{-1} \mathrm{a}^{-1}$ to 17 ind ha ${ }^{-1}$. The sintoc spread on stratification of $\mathrm{C}$ stratum (4 - $20 \mathrm{~m})$, D stratum D (1-4 m), and E stratum (0-1 m) while horizontally, the species existed in diameter class distribution of $10-60 \mathrm{~cm}$.

\section{ACKNOWLEDGMENTS}

We would like to thank the Head of Mount Ciremai National Park of the Ministry of Environment and Forestry Republic of Indonesia for his support during survey. We also thank Toto Supartono, Ilham Adhya, Yayan Hendrayana, Dian, Tito, Yudi, Abdul Hakim, Dedi, and Dasji for helping the data collecting during the research.

\section{REFERENCES}

Baker PJ, Wilson JS. 2000. A quantitative technique for the identification of canopy stratifikasi in tropical and temperate forests. Forest Ecology and Management 127: 77-86.
Batoro J, Siswanto D. Ethnomedicinal survey of plants used by local society in Poncokusumo district, Malang, East JavaProvince,Indonesia. Asian J. Med. Biol. Res. 3 (2): 158-167. doi: 10.3329/ajmbr.v3i2.33563

Ewusie JY. 1990. Pengantar Ekologi Tropika. Kanisus, Yogyakarta.

Hidayat S. 2006. Tumbuhan Obat Langka di Pulau Jawa. Populasi dan Sebaran. Pusat Konservasi Tumbuhan Kebun Raya Bogor-LIPI, Bogor.

Hidayat S, Risna RA. 2007. Kajian ekologi tumbuhan obat langka di Taman Nasional Bromo Tengger Semeru. Biodiversitas 8(3): 169173.

Kastolani W. 2018. How to Conservate in Situ and Ex Situ Community Based Biodiversity Park in Sumedang Regency of West Java Province?. IOP Conf. Ser.: Earth Environ. Sci 145012091.

Kurniawan A, Parikesit. 2008. Persebaran jenis pohon di sepanjang faktor lingkungan di Cagar Alam Pananjung Pangandaran, Jawa Barat. Biodiversitas. Vol. 9.

Kusmana C, Istomo. 1995. Ekologi Hutan. Fakultas Kehutanan, Institut Pertanian, Bogor.

Lemmens RHMJ, Soerianegara I. 1995. PROSEA (Plant Resources of South East Asia) No. 5 (2) Timber Tree: Minor Commercial Timbers. PROSEA Foundation, Bogor.

Ludwig JA, Reynolds JF. Statistical Ecology, A Primer on Methods and Computing. John Wiley \& Sons, New York.

Odum EP.1996. Dasar-dasar ekologi (T. Samingan, Terjemahan). Gadjah Mada University Press, Yogyakarta.

Oladoye AO, Aduradola AM, Adedire MO, Agboola DA. 2014 Composition and stand structure of regenerating tropical rainforest ecosystem in South-western Nigeria. Internasional Journal of Biodiversity and Conservation 6(11):765-776.

Pesiu E, Abdullah MR, Salim J, Salam MR. 2016. Tree species composition in Pulau Bidong And Pulau Redang. Journal of Sustainability Science and Management Special Issue Number 1: The International Seminar on the Straits of Malacca and the South China Sea 2016: 48-60.

Pratiwi SUT, Lagendijk, EL, Hertiani T, de Weert S, Van Den Hondel. 2015. Anti-microbial effects of Indonesian Medicinal Plants Extracts on Planktonic and Biofilm Growth of Pseudomonas aeruginosa and Staphylococcus aureus. International Journal of Pharmacy and Pharmaceutical Sciences 7 (4): 183-191.

Putri WU, Qayim I, Qadir A (2017) Soil seed bank of two karst ecosystems in Bogor, Indonesia: Similarity with the Aboveground Vegetation and its Restoration Potential. J. Trop. Life. Science 7 (3): 224-236.

Rifai MA, Rugayah, Widjaja EA. 1992. Tiga Puluh Tumbuhan Obat Langka Indonesia. Sisipan Floribunda 2:1-28. 17 Juli 1992. Penggalang Taksonomi Tumbuhan Indonesia. Bogor.

Schmidt FR, Ferguson JA. 1951. Rainfall types based on wet and dry period ratios for Indonesia with Western New Guinea, Kementerian Perhubungan, Djawatan Meteorologi dan Geofisik, Jakarta, Verhandelingen, No. 42.

Sujarwo W, Arinasa IBG. 2014. Aromatic Plants in Bali Botanic Garden Indonesia. Journal of Indonesian Natural History 2(1). Susiarti S, Rahayu M, Rugayah. 2018. Diversity of Indonesian Medicinal Plant in The lowland Forest, Bodogol and Its Surrounding of Mount GedePangrango National Park, West Jawa. IOP Conf. Series: Earth and Environmental Science 166012021.

Wiart C. 2006. Plants of Asia and the Pacific. Taylor and Francis Group, LLC, London

Wuu Kuang, Suh. 2011. Taxonomic revision of Cinnamomum (Lauraceae) in Borneo. Blumea 56:241 -264.

Zelnik I, Carni A. 2008. Distribution of plant communities, ecological strategy types and diversity along a moisture gradient. Commun Ecol 9 (1): $1-9$.

Yuanjie $\mathrm{Xu}$, Yaning Chen, Weihong $\mathrm{Li}$, Aihong $\mathrm{Fu}$, Xiaodong $\mathrm{Ma}$, Dongwei Gui, Tapeng Chen. 2010. Distribution pattern of plant species diversity in the mountainous Region of Ili River Valley Xinjiang. Environ Monit Assess 177:681-694. 